\title{
Pentingnya Golden Character
}

\author{
Yotam Teddy Kusnandar' ${ }^{1}$, Alexander Papay ${ }^{2}$ \\ ${ }^{1}$ Sekolah Tinggi Teologi Torsina Surakarta, ${ }^{2}$ Sekolah Tinggi Teologi REAL Batam \\ 'yotam@gmail.com
}

Article History

Received:

Mei 2017 (printed)

Published:

Mei 2017 (printed)

Keywords: achievement;

Bible; character; golden character

\begin{abstract}
Golden character is one of some factors needed by believers in achieving golden age or moment. Golden character is an ideal one based on the true of Bible verses. This is an article which aimed to show the importance of having that character to get a golden achievement. This article used a method of descriptive to describe biblically what the golden character is, then sumed it inductively that believer must have a golden character to achieve the golden moment.
\end{abstract}

\begin{abstract}
Abstrak
Istilah Golden Character atau karakter emas merupakan salah satu faktor yang dibutuhkan untuk dapat mencapai masa keemasan bagi orang percaya. Golden Character merupakan karakter ideal yang didasarkan pada kebenaran alkitabiah. Artikel merupakan refleksi biblikal yang bertujuan untuk menunjukkan pentingnya memiliki karakter emas demi mencapai tujuan pencapaian emas. Artikel ini menggunakan metode deskriptif untuk menggambarkan secara biblikal karakter emas, dan menyimpulkannya secara induktif, bahwa untuk mencapai masa keemasan seseorang perlu memiliki karakter emas.
\end{abstract}

\section{Pendahuluan}

Tema tentang karakter adalah bahasan yang penting, tetapi jarang dibicarakan dan telah diabaikan, bahkan di kalangan Kristen sekalipun. Dua kemungkinan alasan pengabaian ajaran ini adalah : (1) Bahasan ini dianggap kurang menarik dibanding dengan tema doktrinal lainnya; (2) Tidak semua orang suka membahas karakter karena ini menyangkut wilayah "kepribadian" seseorang yang dianggap tidak boleh diusik. Padahal karakter merupakan bagian yang sangat penting dalam kehidupan manusia. 
Akibat dari pengabaian ini banyak orang Kristen yang tidak mengetahui ajaran dari tema yang sangat penting ini, padahal Jerry c. Wofford telah mengaati bahwa "bagi seorang pemimpin gereja, tidak ada atribut yang lebih penting ktimbang karakter". Selanjutnya Wofford menjelaskan, "Dalam pengajaranNya Yesus sangat menekankan karakter pada muridNya. Surat Paulus kepada Timotius dan Titus juga berbicara mengenai karakter pemimpin gereja. Karakter itu meliputi kualitas seperti : integritas, kemurnian moral, kelemahlembutan, dan kesabaran. Kualitas kepemimpinan dibahas diseluruh Perjanjian Baru.

Unsur karakter Kristen sangat penting sehingga Yesus mengambil waktu khusus untuk mengajarkannya kepada mereka yang akan memimpin gereja mula-mula". ${ }^{1}$ Tragisnya, akibat ketidaktahuan ini, banyak orang Kristen tidak bertumbuh dalam karakter Kristen yang baik, dan lebih buruk lagi, tetap merasa bertumbuh padahal mengalami stagnan.

\section{Metodologi}

Artikel ini merupakan refleksi biblikal tentang karakter emas yang dibutuhkan dalam mencapai masa keemasan, baik bagi seseorang maupun gereja secara umum. Karakter emas didasarkan pada idealisasi karakter Kristus yang merupakan patron bagi orang percaya. Penulis menggunakan metode deskriptif, menggambarkan secara ideal karakter emas sesuai dengan Alkitab sebagai norma kebenaran, dan referensi beberapa tokoh tentang karakteristik yang ideal dalam kekristenan. Dalam pengambilan kesimpulan penulis menggunakan metode induktif, setelah mengajukan beberapa premis sebagai indikator karakter emas.

\section{Pembahasan}

Karakter dalam bahasa Yunani, menggunakan istilah charassein yang berarti: to engrave, atau mengukir. ${ }^{2}$ Istilah mengukir di sini menunjukkan bahwa karakter bukanlah sesuatu yang datang seiring manusia dilahirkan, melainkan dibentuk dalam kehidupan manusia tersebut. Menurut Pusat Bahasa Depdiknas karakter adalah "bawaan, hati, jiwa, kepribadian, budi pekerti, perilaku, personalitas, sifat, tabiat,

${ }^{1}$ Wofford J.C, Kepemimpinan Kristen Yang Mengubahkan, (Yogyakarta: ANDI, 2001), 115 -

${ }^{2}$ Bible Works 7 
temperamen, watak." 3 Sementara itu W.J.S Poerwadarminta menyebutkan karakter sebagai "tabiat; watak; sifat-sifat kejiwaan atau budi pekerti yang membedakan seseorang dari yang lainnya". ${ }^{4}$ Dalam Kamus Umum Bahasa Indonesia menuliskan karakter adalah "Tabiat, perangai dan sifat-sifat seseorang." Berkarakter diartikan dengan mempunyai kepribadian, di mana kepribadian diartikan dengan sifat khas dan hakiki seseorang yang membedakan seseorang dari orang lain. Jadi, karakter itu merupakan sifat yang melekat pada kepribadian seseorang, sehingga orang tersebut dibedakan dari yang lain.

Sedang Kristen adalah sebutan bagi seseorang yang telah menerima Yesus Kristus sebagai Tuhan dan Juruselamat secara pribadi serta meneladani hidup dan ajaran-ajaranNya dalam kehiduan sehai-hari. Dengan demikian, karakter Kristen disebut juga sifat-sifat Kristen, yaitu kualitas rohani yang dimiliki seorang Kristen. Karakter Kristen secara ideal memandang kepada Yesus sebagai patron yang satu-satunya yang mendatangkan kemuliaan. Karakter Kristus adalah karakter ideal bagi orang Kristen untuk memiliki karakter emas.

\section{Pembentukan dan Pengembangan Karakter}

Karakter tidak datang sendirinya melainkan harus digali dan dibentuk, ditumbuhkembangkan dan dibangun dengan sadar dan sengaja. Pembentukan pribadi mencakup kombinasi dari beberapa unsur yang tidak mungkin dapat dihindari, yaitu unsur hereditas, unsur lingkungan, dan kebiasaan. (1) Unsur hereditas adalah unsurunsur yang dibawa (diwariskan) dari orang tua melalui proses kelahiran, seperti keadaan fisik, intelektual, emosional, temperamen, dan spiritual; (2) Unsur lingkungan mempunyai peranan dan pengaruh yang besar dalam membentuk karakter dari pribadi seseorang. Unsur lingkungan disini meliputi lingkungan keluarga, lingkungan tradisi dan budaya, serta lingkungan alamiah (tempat tinggal); (3) Unsur kebiasaan adalah suatu tindakan atau tingkah laku yang terus menerus dilakukan menjadi suatu keyakinan atau keharusan. Kebiasaan-kebiasan ini akan turut membetuk karakter seseorang.

Proses pembentukan dan pengembangan karakter pada seseorang dipengaruhi oleh faktor-faktor khas yang ada pada orang yang bersangkutan yang sering juga

\footnotetext{
${ }^{3}$ Kemendiknas. Pembinaan Pendidikan Karakter di Sekolah Menengah Pertama (Jakarta: Kemendiknas, 2010), 15

${ }^{4}$ Departemen Pendidikan dan Kebudayaan, Kamus Besar Bahasa Indonesia (Jakarta: Balai Pustaka, 1980) $617 ; 1088$

${ }^{5}$ J.S. Badudu dan Zain, Kamus Umum Bahasa Indonesia (Jakarta : Pustaka Sinar Harapan, 1996),
} 
disebut faktor bawaan atau faktor endogen atau nature dan oleh faktor lingkungan atau eksogen atau nurture. Pengaruh masyarakat maupun individu sebagai bagian dari masyarakat, adalah faktor lingkungan. Jadi, dalam usaha pengembangan atau pembangunan karakter pada tataran individu dan masyarakat, fokus perhatian kita adalah pada faktor yang bisa kita pengaruhi atau lingkungan, yaitu pada pembentukan lingkungan.

Pendidikan yang berorientasi pada pengembangan karakter tidak bisa dipisahkan dengan pendidikan agama yang dialami oleh seseorang, yang dalam hal ini adalah pendidikan iman Kristen. Doni Koesoema A. mengatakan bahwa "Bagi dia, agama memiliki hubungan vertical antara pribadi dengan Allah (individu dengan yang ilahi / Allah), sedangkan pendidikan karakter hubungan pendidikan karakter adalah horizontal antara manusia di dalam masyarakat." ${ }^{\prime 6}$ Pendidikan iman Kristen dapat diperoleh dari sekolah, gereja dan rumah (keluarga). Keluarga Kristen harus memiliki akar kekristenan yang kuat dengan memberikan pendidikan iman bagi anggotanya.

Dalam konteks pendidikan sekolah, khususnya pada kurikulum KTSP berbasis kompetensi jelas dituntut muatan soft skill yang tertuang dalam emotional intelligence (EQ) dan spiritual intelligence $(S Q)$. Namun penerapannya tidaklah mudah sebab banyak tenaga pendidik tidak memahami apa itu soft skill dan bagaimana penerapannya. Soft skill merupakan bagian ketrampilan dari seseorang yang lebih bersifat pada kehalusan atau sensitifitas perasaan seseorang terhadap lingkungan di sekitarnya. Mengingat soft skill lebih mengarah kepada ketrampilan psikologis maka dampak yang diakibatkan lebih tidak kasat mata namun tetap bisa dirasakan. Akibat yang bisa dirasakan adalah perilaku sopan, disiplin, keteguhan hati, kemampuan kerja sama, membantu orang lain dan lainnya.

Pendidikan atau pengajaran iman Kristen di sekolah, gereja bahkan dalam keluarga harus mampu menumbuhkan karakter bagi setiap orang percaya. Bagus Mustakim melihat pentingnya pendidikan karakter dan mengatakan: "Pendidikan karakter sebagai suatu proses internalisasi sifat-sifat utama yang menjadi ciri khusus dalam sebuah masyarakat ke dalam peserta didik sehingga dapat tumbuh dan bekembang menjadi manusia dewasa sesuai dengan nilai-nilai tersebut."7 Karakter

${ }^{6}$ Doni Koesoema A., Pendidikan Karakter : Mendidik Anak di Zaman Global. (Surabaya: Grasindo, 2006), 250

${ }^{7}$ Bagus Mustakim, Pendidikan Karakter, Membangun Delapan Karakter Emas Menuju Indonesia Bermartabat (Yogyakarta : Samudera Biru, 2011), 29 
Kristen adalah karakter yang menuju kedewasaan dalam Kristus setelah melalui sebuah proses hidup dengan internalisasi nilai-nilai iman Kristen lewat pembelajaran Alkitab.

Pendidikan iman Kristen tidak boleh hanya menggantungkan pada satu sisi saja, bahkan gereja sekalipun. ${ }^{8}$ Harus ada sinergi yang kuat antara gereja, sekolah dan keluarga dalam memberikan pendidikan iman Kristen sebagai landasan kuat pembentukan dan pengembangan karakter emas. Secara umum ketiga unsur yang disebut pada bagian atas membentuk pribadi seseorang. Tetapi, ada lagi satu unsur yang membedakan orang Kristen dari yang bukan Kristen, yaitu unsur regenerasi atau kelahiran baru, yang bersifat radikal dan supranatural. Justru unsur regenerasi ini sangat menentukan dalam pembentukan karakter Kristen, karena tanpa regenerasi ini kita gagal menyenangkan Allah.

Sekolah sebagai tempat pendidikan sekaligus pembelajaran bagi orang percaya memiliki andil dalam membentuk karakter Kristen yang bernilai emas. Demikian juga gereja, terlebih keluarga. Proses pembelajaran yang terjadi akan lebih kompleks lagi karena mengarah kepada tujuan akhirnya yakni seorang percaya dapat bertingkah laku atau memiliki kepribadian yang lebih baik (bersifat operasional) dari yang lain. Dalam proses pendidikan iman Kristen, tujuan pendidikan dan pembelajaran yang dilakukan baik di sekolah, gereja dan keluarga memberikan pengetahuan kepada peserta didik untuk mengenal Yesus sebagai Tuhan dan Juru Selamat dan pembentukan kerohanian serta pertumbuhan karakter. Sehingga dalam hal ini, pendidikan moral dan karakter sebenarnya tidak terpisahkan dari pembentukan kerohanian yang merupakan kesatuan dalam proses belajar tersebut.

\section{Membangun Karakter Emas Kekristenan}

Membangun karakter emas berarti membangun suatu pola dari sikap yang hendak didemonstrasikan dalam hubungannya antara satu dengan lainnya. Sikap yang didemonstrasikan itu merupakan ciri khas moral atau etika Kristen. Dalam membangun karakter emas baik gereja, sekolah dan keluarga semestinya mengarisbawahi bahwa Alkitab memberikan blue print dalam pembentukan kerohanian atau pengembangan moral dan karakter (Mazmur 78:1-8). Orang percaya sebagai peserta didik dalam proses

${ }^{8}$ Harls Evan Rianto Siahaan, "Hikmat Sebagai Implikasi Pendidikan Kristiani Dalam Keluarga: Refleksi 1 Raja-Raja 3:1-15,” DUNAMIS (Jurnal Teologi dan Pendidikan Kristiani) 1, no. 1 (2016): 1530, www.sttintheos.ac.id/e-journal/index.php/dunamis. 
belajar iman Kriseten harus menempatkan Kristus sebagai pusat kehidupan mereka, sehingga pembentukan karakter emas orang percaya menjadi sebuah keniscayaan.

Tidak cukup hanya teori karakter, tetapi harus sampai masuk kedalam hati hingga menjadi energi penggerak untuk dilakukan. Apa artinya jika sesuatu yang hebat tapi hanya dimuseumkan. Alasan penting mengapa kita perlu mengajarkan dan menampilkan karakter Kristen adalah: (1) Kemerosotam moral. Karena saat ini sudah begitu luas kalangan yang merasakan terjadinya kemerosotan moral. Pengajaran karakter adalah suatu perlawanan terhadap kemerosotan moral dan terhadap etika modern yang rasionalistik yang dipengaruhi oleh pencerahan dan individualistik; (2) Bahaya Pluralisme. Dalam zaman globalisasi dari postmodern saat ini kita semakin menyadari berbagai aturan moral yang berbeda dari berbagai budaya yang berbeda. Saat ini kita hidup disuatu zaman perjumpaan global dan keragaman budaya, dan itu membutuhkan kemampuan untuk beradaptasi; (3) Pudarnya semangat keteladan. Karakter dibentuk oleh orang-orang lain yang menjadi model atau mentor yang kita ikuti. Orang tua, guru, pembina, pelatih yang menjadi model atau teladan bagi kita turut membentuk karakter kita.

Dengan dituntun atau mengikuti dan meneladani para pembina atau sosok lain yang layak diteladani kita belajar mengenali dan mewujudkan berbagai disposisi, kebiasaan, dan keterampilan emosional dan intelektual yang dinyatakan oleh berbagai kebajikan. Sayangnya, kebanyakan teori etika individualistik dan rasionalistik modern kurang memperhatikan pengaruh-pengaruh ini, atau dengan kata lain semangat untuk mewarisi keteladanan kebenaran ini semakin memudar. Karakter tidak dapat secara pintas didapatkan oleh seseorang, namun semua itu melalui proses yang panjang. Operasi adalah jalan pintas untuk seseorang memperbaiki seorang yang kurang dalam fisiknya. Namun, tidak ada cara operasi untuk mengubah karakter atau sifat kita.

Karakter harus terlihat lewat hubungan dan contoh. Artinya, jika mengajar adalah sebuah proses memindahkan pengetahuan, dan tindakan menumpang-tangan adalah mengimpartasi roh, tetapi hubungan dan contoh (teladan) adalah sebuah proses memindahkan karakter. Pembentukan karakter emas membutuhkan teladan, tidak hanya sekadar "guru" yang mengajarkan prinsip alkitabiah tersebut. ${ }^{9}$ Selain itu juga ada proses

\footnotetext{
${ }^{9}$ Bimo Setyo Utomo, “(R)Evolusi Guru Pendidikan Agama Kristen Dalam Mentransformasi Kehidupan Siswa,” DUNAMIS (Jurnal Teologi dan Pendidikan Kristiani) 1, no. 2 (April 30, 2017): 102116, accessed Mei 12, 2017, http://sttintheos.ac.id/e-journal/index.php/dunamis/article/view/111.
} 
pendisiplinan yang dilandaskan pada kebenaran Alkitab yang tidak menyalahi dan melukai mereka yang didisiplin. ${ }^{10}$

Yohanes 12:26 mengatakan: "Barangsiapa melayani Aku, ia harus mengikut Aku dan di mana Aku berada, di situpun pelayan-Ku akan berada. Barangsiapa melayani Aku, ia akan dihormati Bapa." Mengikut Yesus selalu berbicara tentang journey dan destiny. Journey adalah perjalanan, yakni tindakan melakukan perjalanan ke suatu tempat. Sedangkan destiny adalah tujuan yang akan dituju di masa depan. Namun perhatikan prisnisp ini, bahwa seseorang akan tidak sampai pada sebuah tujuan tanpa perjalanan; dan sebaliknya, perjalanan tanpa tujuan membuat seseorang hanya berputarputar. Salah satu contoh tokoh Alkitab yang melakukan hal ini adalah Elia dan Elisa. Dalam 2 Raja-Raja 2, Elisa mengikut Elia dari Gilgal-Bethel-Yeriko - Yordan. Sebagai seorang murid, Elisa mengikuti Elia kemanapun Elia pergi. Ini merupakan keteladanan yang murid lakukan kepada pemimpinnya.

Seorang pemimpin dilahirkan lewat proses yang tidak mudah. Pemimpin yang berkarakter emas akan mengalami proses seperti emas yang sedang dimurnikan. Tidak mudah namun menghsilkan sesuatu yang berharga. Apa yang lebih penting dalam hidup ini bukan apa yang hendak dicapai (reputasi), tetapi perjalanan mencapai tujuan tersebutlah yang melahirkan karakter. Pencapaian penting, namun harus didasari dengan karakteristik Kristus untuk menggapainya. Menjadi apa dalam perjalanan inilah yang membentuk karakter kita. Keberhasilan dikuatkan atau dihancurkan oleh karakter. Jika reputasi dibuat dari suatu kejadian, maka karakter dibangun seumur hidup.

Dalam Roma 12:1-2 ada frasa“berubahlah oleh pembaharuan budimu..." beberapa terjemahan Alkitab Bahasa Inggris memberikan penekanan yang berbeda, seperti: Renewing of your mind (KJV, NIV), Change the way of your think (God's Word), Be transformed or Change (Amplified), Fix your attention on God (Messages). Dari beberapa frasa yang digunakan, dengan mempertimbangkan penggunaan bahasa Yunani sebagai bahasa asli Perjanjian Baru, maka diperoleh beberapa pemahaman: (1) Berubah ke arah yang semakin baik. Istilah yang digunakan adalah $\mu \varepsilon \tau \alpha \mu о \rho \varphi о v \tilde{\sigma} \theta \varepsilon$

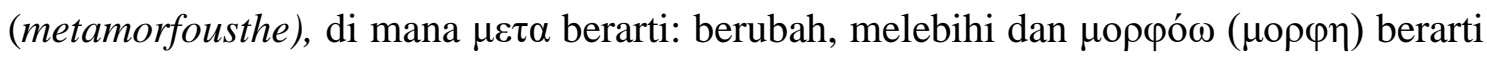
bentuk; atau (2) Berubah terus-menerus. Mempertimbangkan $\mu \varepsilon \tau \alpha \mu о \rho \varphi о \tilde{\sigma} \sigma \varepsilon$

\footnotetext{
${ }^{10}$ Yushak Soesilo, "Penggunaan Rotan Dalam Pendisiplinan Anak Menurut Kitab Amsal 23:1314," DUNAMIS ( Jurnal Teologi dan Pendidikan Kristiani ) 1, no. 1 (2016): 1-14, www.sttintheos.ac.id/e-journal/index.php/dunamis.
} 
(metamorfousthe) dalam penggunaan tense Imperatif Aorist yang dapat berarti: Mulailah berubah!, dan Imperatif Present yang berarti: Teruslah Berubah!

Kata $\mu \varepsilon \tau \alpha \mu о \rho \varphi о \tilde{\sigma} \theta \varepsilon$ (metamorfousthe) biasanya digambarkan dengan proses metamorfosa kupu-kupu. Gambar di bawah akan menjelaskan proses yang diungkapkan dalam kata $\mu \varepsilon \tau \alpha \mu о \rho \varphi о \tilde{\sigma} \theta \varepsilon$ (metamorfousthe), di mana perubahan tidak hanya dialami dalam waktu sekali saja, namun berlangsung terus-menerus, berubah ke arah yang lebih baik. Perubahan orang Kristen perubahan kita selalu mengarah pada karakter Kristus.

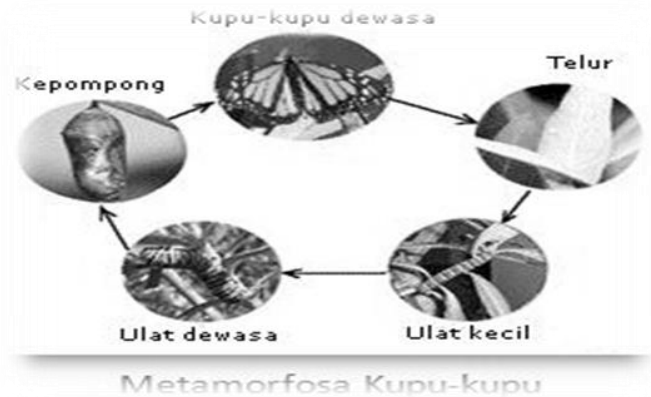

Karakter yang baik akan memberikan keuntungan. Dalam Matius 6:33 disebutkan: "Tetapi carilah dahulu Kerajaan Allah dan kebenarannya, maka semuanya

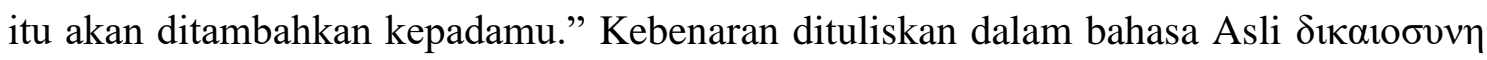
(dikaiosune) yang memiliki pengertian: rigth position (posisi yang benar), right relationship (hubungan yang benar), dan good character (karakter yang benar/baik). Allah menginginkan supaya kita mencari, mengejar, dan memiliki good character. Saat kita mengejar yang baik dan benar itu, maka kata Firman Tuhan, semuanya (yang baik dan benar) akan ditambahkan atau diberikan kepada kita. Karakter dibentuk, tidak diciptakan. Dibentuk artinya harus melalui proses. Proses berbicara tentang waktu. Tuhan kita adalah Tuhan yang cinta akan proses. Namun seringkali kita anak-anakNya hanya mau yang instan. Padahal di dalam proses tersebut, Tuhan membentuk karakter kita menjadi karakter emas.

\section{Karakter adalah Kunci Kepemimpinan}

Karakter merupakan kunci dalam sebuah kepemimpinan; pemimpin akan gagal jika mengorbankan karakter mereka. Karakter adalah sebuah kekuatan yang tidak kelihatan. Karakter bertumbuh melalui proses dan ujian. Karakter dapat dibangun melalui masalah yang terjadi dan aktivitas sehari-hari. Masalah yang terjadi lewat segala cobaan menjadi cara untuk membentuk karakter seseorang. Amsal 27:17 mengatakan: "Besi menajamkan besi, orang menajamkan sesamanya." Karakter yang 
baik menghasilkan buah-buah yang unggul dan berkualitas Buah-buah yang bermanfaat bagi kehidupan kita dan orang lain. Buah-buah dari karakter antara lain: Integritas menghasilkan kewibawaan, tanggung jawab menghasilkan kedewasaan, kejujuran menghasilkan kepercayaan, ketulusan menghasilkan persahabatan, iman menghasilkan kekuatan, ketekunan menghasilkan pengharapan, dan lain sebagainya. ${ }^{11}$ Ketika kita dipanggil TUHAN yang diingat adalah karakter.

Karakter dibentuk lewat aktivitas. Lumpkin, Stoll \& Beller dalam Journal Positive Character Development in School Sport Programs menyatakan "character values include loyalty, dedication, sacrifice, teamwork, and good citizenship... honesty, fairness, fair play, justice, and responsibility." ${ }^{2}$ Dari aktivitas yang dilakukan, kita semakin dibentuk olehnya dan di dalamnya; karena lingkungan juga mempengaruhi karakter kita bertumbuh seperti apa. Oleh sebab itu kita harus tahu dan dapat memilih dengan bijak aktivitas bagaimana yang dapat membentuk karakter kita supaya bertumbuh ke arak Kristus.

\section{Karakter Yesus Kristus}

Karakter Kristus merupakan karakter ideal dan parameter bagi kekristenan; setiap orang percaya harus tumbuh dalam karakter Kristus. Ada tiga hal berkaitan dengan karakter Kristus, yakni: Karakter yang berhubungan dengan kualitas diri-Nya, karakter yang berhubungan dengan orang-orang sekitar-Nya, karakter yang berhubungan dengan penderitaan dan tekanan. Yesus menjadi patron karakteristik orang percaya, sehingga orang yang hidup di dalam iman kepada Tuhan Yesus Kristus harus menuju karakteristik tersebut.

Berkaitan dengan kualitas diriNya, maka karakter tersebut adalah: Integritas (berani karena benar, jujur, tidak tamak, rajin, setia, dapat dipercaya, hemat, tulus, saleh, setia); kreatif; sopan-santun atau tertib; smart (tajam dan cerdas, berinisiatif dan cepat tanggap, cermat); cautious (penuh pertimbangan); arif (discreet) dan bijaksana (wise); fair (adil); antusias; fleksibel dan tepat waktu; berdaya guna; bertanggungjawab; rendah hati.

Selain itu ada karakter Kristus yang berhubungan dengan orang-orang sekitarNya, seperti: penuh perhatian (attentive); gentle (lembut); tahu berterima kasih (grateful); hormat/menghargai (honor/respectful); bisa meyakinkan orang (persuasive);

\footnotetext{
${ }^{11}$ Ezra Yakoep, Succes Through Character, (Yogyakarta: ANDI, 2006), 13-14.

${ }^{12}$ Beller \& Jennifer, Journal Positive Character Development, 2002, 2
} 
peka (sensitive); ramah/suka memberi tumpangan/suka menjamu (hospitable); tak mudah mengha-kimi/bersikap toleran (tolerant); lembut hati/suka mengalah (meek); pemaaf (forgiving); penuh kebaikan/kasih (benevolent); simpati/berbelaskasihan (compassionate); murah hati (generous).

Dan karakter Kristus yang berhubungan dengan penderitaan dan tekanan adalah: waspada/siaga (alert); tekun/gigih/tabah (endurance); penuh sukacita (joyful); setia (loyal); taat (obedient); sabar (patient); tidak kuatir/tidak takut/merasa aman (secure); penguasaan diri (self control); tegas (decisive); bertekad kuat/ulet (determinate).

Karakter-karakter tersebutlah yang dinamakan karakter emas atau karakter Kristus, yang harus dimiliki oleh orang percaya dalam kehidupannya. Billy Graham berpendapat bahwa, "Ketika kekayaan kita hilang tidak ada yang hilang karena kita bisa bekerja kembali. Tetapi jika karakter hilang maka semuanya akan lenyap"13 perhatikan Terjemahan MSG dalam Efesus 4:22, "A life renewed from the inside and working itself into your conduct as God accurately reproduces His Character in you (Kehidupan baru dikerjakan dari dalam dan bekerja sendiri didalam perilaku Anda sebagai reproduksi yang akurat dari karakter-Nya di dalam Anda). Demikian juga dalam Kolose 3:9-10, "Don't lie to one another. You're done with that old life. It's like a filthy set of ill-fitting clothes you've stripped off and put in the fire. Now you've dressed in a new wardrobe. Every item of your new way of life is custom-made by the Creator, with His Label on it (Jangan berbohong satu sama lain. Anda sudah selesai dengan kehidupan lama. Ini seperti satu set pakaian kotor yang tidak pas untuk Anda dan hal itu sudah ditanggalkan dan dimasukkan ke dalam api. Sekarang Anda sudah mengenakan pakaian baru. Setiap item dari cara baru hidup Anda adalah custom-made oleh Sang Pencipta, dengan Label-Nya di atasnya).

Karakter Kristus merupakan idealisasi atau patron biblikal yang harus dipenuhi oleh setiap orang yang hidup di dalam Kristus. Karakter inilah yang menjadi persyaratan atau kualifikasi untuk seseorang dapat menuju dan mencapai masa keemasan sesuai dalam rancangan dan konsepsi Tuhan. Namun demikian, proses perubahan dalam membentuk karakteristik Kristus sebagai karakter emas tidak dapat dilakukan dengan mengandalkan upaya diri sendiri, melainkan membutuhkan kekuatan

\footnotetext{
${ }^{13}$ Gede Raka dkk. Pendidikan Karakter di Sekolah dari Gagasan ke Tindakan (Jakarta : Kompas Gramedia, 2011), 36
} 
Roh Kudus. ${ }^{14}$ Roh Kudus sebagai dinamisator yang akan memberikan kekuatan setiap orang percaya untuk tumbuh dalam karakter Kristus sebagai karakter emas kekristenan di masa kini.

\section{Kesimpulan}

Penulis menggunakan gambaran sebuah pesawat, yang terdiri atas: kerangka, interior, dan mesinnya. Kerangka menggambarkan atiitude atau perilaku; interior adalah gambaran dari kepribadian dan mesin adalah karakter. Kehidupan Kristen digerakkan oleh karakteristik yang dibentuk dalam sebuah proses kehidupan dengan patron Yesus Kristus sebagai model karakter emas. Filipi 2:5 berkata: "Hendaklah kamu dalam hidupmu bersama menaruh pikiran dan perasaan yang terdapat juga dalam Kristus Yesus", yang dlaam Amplified Bible: Let this same attitude and purpose and mind be in you which was in Christ Jesus. Artinya, Alkitab menandaskan bahwa kesamaan pikiran dan perasaan merupakan standar hidup orang percaya; dengan demikian kesamaan karakter pun akan menjadi sebuah keniscayaan dalam hidup orang percaya.

\section{Referensi}

A, Doni Koesoema. Pendidikan Karakter : Mendidik Anak di Zaman Global. Surabaya: Grasindo, 2006

Badudu, J.S. dan Zain, Kamus Umum Bahasa Indonesia, Jakarta : Pustaka Sinar Harapan, 1996

Beller \& Jennifer, Journal Positive Character Development, 2002

Bible Works 7

C, Wofford J.. Kepemimpinan Kristen Yang Mengubahkan, Yogyakarta: ANDI, 2001

Departemen Pendidikan dan Kebudayaan, Kamus Besar Bahasa Indonesia, Jakarta: Balai Pustaka, 1980

Kamus Umum Bahasa Indonesia, Jakarta: Balai Pustaka

Kamus Besar Bahasa Indonesia, Edisi Baru, Jakarta: Pustaka Phoenix

Kemendiknas. Pembinaan Pendidikan Karakter di Sekolah Menengah Pertama Jakarta: Kemendiknas, 2010

Mustakim, Bagus Pendidikan Karakter, Membangun Delapan Karakter Emas Menuju Indonesia Bermartabat, Yogyakarta : Samudera Biru, 2011

Raka Gede dkk. Pendidikan Karakter di Sekolah dari Gagasan ke Tindakan, Jakarta : Kompas Gramedia, 2011

Siahaan, Harls Evan Rianto. "Hikmat Sebagai Implikasi Pendidikan Kristiani Dalam Keluarga: Refleksi 1 Raja-Raja 3:1-15.” DUNAMIS (Jurnal Teologi dan Pendidikan Kristiani) 1, no. 1 (2016): 15-30. www.sttintheos.ac.id/ejournal/index.php/dunamis.

\footnotetext{
${ }^{14} Y$ ushak Soesilo, "PENGALAMAN PRIBADI DENGAN ROH KUDUS SEBAGAI INDIKATOR KUALITAS PELAYANAN,” Jurnal Antusias 1, no. 3 (September 1, 2011): 109-117, accessed March 29, 2017, http://www.sttintheos.ac.id/e-journal/index.php/antusias/article/view/79/78.
} 
Soesilo, Yushak. "PENGALAMAN PRIBADI DENGAN ROH KUDUS SEBAGAI INDIKATOR KUALITAS PELAYANAN.” Jurnal Antusias 1, no. 3 (September 1, 2011): 109-117. Accessed October 29, 2017. http://www.sttintheos.ac.id/ejournal/index.php/antusias/article/view/79/78.

_. "Penggunaan Rotan Dalam Pendisiplinan Anak Menurut Kitab Amsal 23:1314." DUNAMIS ( Jurnal Teologi dan Pendidikan Kristiani ) 1, no. 1 (2016): 1-14. www.sttintheos.ac.id/e-journal/index.php/dunamis.

Utomo, Bimo Setyo. "(R)Evolusi Guru Pendidikan Agama Kristen Dalam Mentransformasi Kehidupan Siswa." DUNAMIS (Jurnal Teologi dan Pendidikan Kristiani) 1, no. 2 (April 30, 2017): 102-116. Accessed July 26, 2017. http://sttintheos.ac.id/e-journal/index.php/dunamis/article/view/111.

Yakoep, Ezra. Succes Through Character, Yogyakarta: ANDI, 2006 